\title{
BUDIDAYA AYAM KAMPUNG PADA KELOMPOK IBU RUMAH TANGGA SION KEFAMENANU NTT
}

\author{
Charles Venirius Lisnahan ${ }^{1)}$, Agustinus Agung Dethan²), Polikarpia Wilhelmina Bani ${ }^{3)}$ \\ Program Studi Peternakan,Fakultas Pertanian Universitas Timor,Indonesia ${ }^{1,2)}$ \\ Program Studi Biologi,Fakultas Pertanian Universitas Timor,Indonesia ${ }^{3)}$ \\ Email: charleslisnahan03@ gmail.com
}

\begin{tabular}{|l|l|l|}
\hline Dikirim: 19-10-2020 & Direvisi: 25-11-2020 & Diterbitkan: 28-02-2021 \\
\hline
\end{tabular}

\begin{abstract}
Abstrak
Pengabdian pada masyarakat ini bertujuan meningkatkan kesejahteraan melalui budidaya ayam kampung ramah lingkungan pada kelompok ibu rumah tangga Sion Kefamenanu, Nusa Tenggara Timur. Dalam pengabdian ini digunakan metode participatory action research, kelompok ibu rumah tangga "Perempuan Sion, Ketua RT dan Tim pelaksana secara bersama-sama dilibatkan dalam penentuan jenis kegiatan dan pelaksanaan kegiatan di lapangan. Tahapan-tahapan kegiatan dan solusi mengatasi permasalahan kelompok mitra meliputi kegiatan persiapan secara bersama antara tim pengabdian dengan kelompok mitra menetapkan jenis kegiatan yang telah disusun tim berdasar hasil analisis situasi awal dan disesuaikan dengan kebutuhan dan kondisi aktual. Kegiatan dilanjutkan dengan penyuluhan dan pelatihan/pendampingan oleh dosen dan tim pendamping sekaligus praktek pelaksanaan kegiatan untuk meningkatkan kemampuan peternak/kelompok. Tahapan kegiatan meliputi manajemen penetasan, pembuatan pakan komplit, pemeliharaan fase starter dalam brooding, penataan kandang untuk pemeliharaan fase grower, pembuatan pupuk bokashi dengan memanfaatkan ekskreta ayam, dicampur dengan EM4 dan gula lontar, penjualan ayam dan perhitungan ekonominya serta evaluasi kegiatan sesuai tahapan pelaksanaan. Hasil yang dicapai adalah ketrampilan kelompok peternak meningkat dengan memanfaatkan penggunaan mesin tetas dan dapat menetaskan telur ayam kampung dengan baik, pemeliharaan dengan indukan buatan (brooding) dan pemeliharaan fase pertumbuhan (grower) serta manajemen pemeliharaan lainnya seperti pencegahan penyakit dan vaksinasi, pencampuran pakan dan lain-lain dapat dilakukan dengan mudah oleh kelompok peternak sehingga populasi maupun produktivitas ternak ayam kampung bertambah. Terjadi peningkatan pendapatan dan kesejahteraan kelompok peternak dengan keuntungan Rp. 3.250.000 dengan volume pemeliharaan 100 ekor ayam kampung sejak DOC sampai umur 3-5 bulan.
\end{abstract}

\section{Kata Kunci: ayam kampung, penetasan, pakan, bokashi}

\begin{abstract}
This community service aims to improve community's welfare through the cultivation of eco-friendly native chickens in Sion's housewives community, Kefamenanu, East Nusa Tenggara Province. In this community service, the participatory action research method is used, the group of Sion's housewives, the chairman of neighbourhood and community servicer team are involved in determining the activity and the implementation of activities in the field. The stages of activities and solutions to overcome the problems of the partner group include preparation activities of the community servicer team and the partner group to determine the activities that the team has compiled based on the results of the initial situation analysis and adjusted to actual needs and conditions. The activity was continued with counseling and training/mentoring by lecturers and the companion team as well as practical implementation of activities
\end{abstract}


to improve the ability of breeders/groups. The stages of activities include hatchery management, complete feed making, maintenance of the starter phase in brooding, arrangement of cages for the maintenance of the grower phase, manufacture of organic fertilizer using chicken excreta, mixed with EM4 and palm sugar, chicken sales and economic calculations and evaluation of activities according to the implementation stages. The results achieved were that the skills of farmer groups improved by utilizing the use of hatching machines and being able to hatch native chicken eggs properly, with brooding maintenance and grower maintenance as well as other maintenance management such as disease prevention and vaccination, mixing of feed and others can be done easily by breeder groups so that the population and productivity of native chickens increase. There was an increase in the income and welfare of the breeder groups with a profit of IDR 3,250,000 with a maintenance volume of 100 native chickens from day old chick until the age of 3-5 months.

Keywords: native chicken, hatching, feed, bokashi

\section{PENDAHULUAN}

Ayam kampung dalam perkembangannya mampu menyediakan 6,01\% kebutuhan protein bagi masyarakat secara nasional dengan total populasi tahun 2019 sebesar 311.912 .000 ekor (Kementrian Pertanian Republik Indonesia, 2019). Hal ini merupakan peluang bagi peternak mengembangkan populasi maupun produksi daging dan telur dalam mencukupi kebutuhan protein hewani bagi masyarakat. Selain itu juga untuk meningkatkan pendapatan peternak. Menyadari hal tersebut, di Kefamenanu, Nusa tenggara Timur telah terbentuk kelompok peternak ayam kampung yaitu kelompok ibu-ibu rumah tangga "Perempuan Sion" untuk menopang perekonomian keluarga. Kelompok ini berdiri sejak 1 Mei 2017 yang terdiri dari 6 orang. Ayam kampung yang mereka pelihara berkisar 50 - 100 ekor per periode. Kelompok ini selain beternak, juga bertani khususnya tanaman sayur-sayuran dengan tujuan memanfaatkan ekskreta ayam untuk pemupukan.

Kendala yang dihadapi kelompok selama pemeliharaan yaitu manajemen pemeliharaan yang intensif yang belum dikuasai karena ternak ini hanya dipelihara begitu saja dalam skala rumah tangga. Permasalahan dimulai dengan adanya pengeraman telur secara alami (bukan dengan mesin tetas) sehingga popoulasi ayam berkembang lambat. Perkandangan yang digunakan cukup layak tetapi penataan dan kebersihan kandang yang kurang baik dapat mengganggu pertumbuhan ternak, kenyamanan dan kesehatan peternak, dan akibat lebih lanjut menyebabkan polusi udara di lingkungan sekitar kandang. Pemeliharaan biasanya memanfaatkan atau menggunakan limbah rumah tangga, tanpa memperhatikan manajemen kandang, pencegahan penyakit dan terutama pakan yang berkualitas dalam jumlah yang cukup dan selalu tersedia. Selain itu permasalan yang terjadi adalah kurangnya pengetahuan tentang pakan yang berkualitas bagi ternak ayam untuk meningkatkan produktivitas belum banyak diketahui kelompok.

Dengan demikian permasalahan yang dihadapi kelompok ibu-ibu rumah tangga "Perempuan Sion" adalah usaha pemeliharaan ayam kampung belum produktif. Hal ini ditandai dengan perkembangan populasi dan pertumbuhan ayam kampung yang lambat sehingga waktu panen lebih lama. Pertumbuhan ayam yang lambat disebabkan oleh pakan yang diberikan tergolong kurang berkualitas atau kurang sesuai dengan kebutuhan normal ternak ayam untuk bertumbuh secara optimal. Pakan yang diberikan selain limbah rumah tangga juga berupa jagung dan 
selanjutnya ayam kampung dibiarkan mencari pakan tambahan di pekarangan rumah. Hal ini karena pakan konvensional yang mahal (Rp. 9.000 - 10.000/kg) menyebabkan peternak sulit menjangkaunya. Selain pakan, manajemen pemberian pakan tidak memperhatikan tempat pakan yang layak, dan kebanyakan pakan dihambur di tanah (ternak mematuk pakan di tanah) yang memungkinkan ternak maupun peternaknya kurang nyaman. Kandang yang ada merupakan kandang sederhana, dan penataan di dalamnya belum memenuhi standar misalnya tempat pakan dan tempat minum yang memadai. Ekskreta di dalam kandang atau yang dibuang di luar kandang, belum ada upaya untuk pengolahan lebih lanjut untuk mengurangi resiko penyakit maupun pencemaran lingkungan. Berdasarkan permasalahan tersebut maka dilakukan suatu pengabdian budidaya ayam kampung ramah lingkungan pada Kelompok Ibu Rumah Tangga Sion Kefamenau NTT.

Tujuan Kegiatan pengabdian ini adalah meningkatkan keterampilan kelompok peternak dalam manajemen penetasan, budidaya ayam kampung, melatih kelompok peternak dalam menyiapkan kandang yang lebih nyaman dan sehat untuk pertumbuhan ayam sejak fase starter (day old chick/DOC) sampai produksi, meningkatkan keterampilan dan kemampuan mencampur pakan dari bahan-bahan lokal yang lebih murah namun berkualitas, melatih kelompok peternak memanfaatkan kotoran/eksreta ayam dan limbah kandang lainnya untuk pembuatan pupuk organik, dan meningkatkan pendapatan kelompok peternak.

Sasaran yang ingin dicapai adalah dengan kandang yang baik, peternak dapat beraktivitas lebih nyaman, dan ternak ayam berada dalam zona nyaman untuk pertumbuhan dan berproduksi, kelompok peternak menghasilkan pakan ayam kampung terutama pakan komplit dan digunakan atau dikonsumsi ayam untuk memacu pertumbuhannya. Kelompok peternak terampil membuat pupuk organik (bokashi) dan polusi di sekitar kandang diminimalkan. Dengan adanya pemanfaatan limbah kandang ini untuk pembuatan pupuk bokashi dari ekskreta ayam, menciptakan lingkungan yang bersih dan pupuk tersebut dimanfaatkan untuk tanaman disekitar lokasi kandang. Peternak diharapkan termotivasi dalam pengembangan ternak ayam kampung dengan tahapan kegiatan yang dilaksanakan, karena mudah dan praktis. Hal ini memberikan nilai tambah untuk peningkatan kesejahteraan peternak khususnya peternak ayam kampung.

\section{METODE}

Pengabdian ini dilaksanakan di Kelurahan Sasi, Kecamatan Kefamenanu, Kabupaten Timor Tengah Utara, selama 5 bulan sejak bulan Mei sampai September 2020. Metode yang digunakan dalam kegiatan ini yaitu metode participatory action research. Kelompok ibu-ibu rumah tangga "Perempuan Sion, Ketua RT dan tim pelaksana secara bersama-sama dilibatkan dalam penentuan jenis kegiatan dan pelaksanaan kegiatan di lapangan. Kegiatan pendampingan dilakukan oleh tim pendukung mahasiswa (S-1) sebagai sarana monitoring dan evaluasi kegiatan sekaligus sebagai sarana peningkatan ketrampilan mahasiswa dan pembekalan sebelum memasuki dunia kerja. Tahapan-tahapan kegiatan dan solusi mengatasi permasalahan kelompok mitra adalah kegiatan persiapan merupakan kegiatan bersama antara tim pengabdian dengan kelompok sasaran untuk menetapkan jenis kegiatan yang telah disusun tim berdasar hasil analisis situasi awal yang akan 
disesuaikan dengan kebutuhan dan kondisi aktual. Kegiatan dilanjutkan dengan penyuluhan dan pelatihan/pendampingan oleh dosen dan tim pendamping sekaligus praktek pelaksanaan kegiatan untuk meningkatkan kemampuan peternak/kelompok. Pada tahapan kegiatan ini dilakukan dengan presentasi kegiatan tentang cara atau model yang dikembangkan masing-masing kegiatan sekaligus praktek atau pelatihan dan aplikasi lapangan. Tahapan-tapan pada kegiatan ini dibagi menjadi:

1. Manajemen penetasan. Melatih kelompok mitra untuk penetasan telur secara buatan dengan memanfaatkan mesin tetas. Pelatihan ini dilakukan dari bagaimana menyeleksi telur tetas, mempersiapkan mesin, periode penetasan selama 20-22 hari dan penanganan DOC di dalam indukan buatan. Pada periode penetasan, dilatih menyortir telur dengan candling (teropong), sehingga telur yang infertil pada umur 3-4 hari dikeluarkan dari mesin tetas dan dikonsumsi atau dijual dengan harga yang lebih rendah dari harga telur ayam kampung. Limbah mesin tetas (kerabang telur) digunakan sebagai sumber kalsium pada pembuatan pakan komplit. Kerabang telur dijemur kemudian diolah menjadi tepung kalsium yang dicampur dalam pakan. Luaran yang diharapkan yaitu peternak dapat menetaskan telur secara buatan dan memelihara DOC (umur starter) dalam brooder (indukan buatan) sampai umur 6 minggu.

2. Pembuatan pakan komplit. Pada saat pengeraman telur, pakan sudah harus disiapkan. Pakan dicampur dengan komposisi nutrient yang seimbang sesuai dengan kebutuhan setiap fase pemeliharaan (starter, grower, pullet dan layer). Komposisi nutrien pakan didasarkan pada hasil penelitian (Lisnahan, 2018). Bahan pakan yang digunakan adalah bahan-bahan lokal yang relatif murah dan tersedia seperti jagung kuning, bekatul, tepung ikan, bungkil kedelai, kapur, premix vitamin dan mineral, dan asam amino metionin (dl-methionine) dan lisin (1lysine $\mathrm{HCl}$ ). Selain tepung kapur, juga digunakan tepung kerabang (limbah penetasan) sebagai sumber kalsium. Komposisi nutrien pakan pada pemeliharaan fase starter adalah: ME 2958,21 $\mathrm{kcal} / \mathrm{kg}$, protein kasar 16,76\%, lemak kasar 6\%, abu 7\%, serat kasar 7\%, methionine 0,3\%, lisin $0,85 \%$, kalsium $1,60 \%$ dan fosfor $0,6 \%$ (Lisnahan et al., 2017a).

3. Penataan kandang untuk pemeliharaan fase grower. Kandang ditata dengan ukuran yang lebih luas yaitu 5 ekor $/ \mathrm{m}^{2}$. Difumigasi dengan rodalon sebanyak 3 kali. Dalam kandang ditaruh tempat pakan berukuran $3 \mathrm{~kg}$ sebanyak 6 buah dan 2 buah galon air berukuran 5 liter. Alas kandang diberikan sekam padi, dicampur kapur.

4. Pemeliharaan fase grower. Pada pemeliharaan fase ini, ayam kampung tidak dipisahkan antara jantan dan betina. Pakan yang diberikan disesuaikan dengan kebutuhan baik makro maupun mikro nutriennya. Bahan pakan seperti pada fase starter, tetapi komposisi nutrien pakan seperti protein kasar, dan asam amino lebih rendah dibanding pada fase starter. Komposisi nutrient pakan pada fase grower adalah ME $2971 \mathrm{kcal} / \mathrm{kg}$, protein kasar 15,26\%, lemak kasar 6,18\%, abu 7,64\%, serat kasar 7,24\%, methionine 0,25\%, lisin 0,60\%, kalsium $1,47 \%$ dan fosfor $0,60 \%$ (Lisnahan et al., 2017b). Pemberian pakan dilakukan 2 kali sehari sedangkan air minum diganti setiap hari.

5. Pembuatan pupuk bokasi dengan memanfaatkan ekskreta ayam, dicampur dengan EM4 dan gula lontar (Kusuma \& Erviana, 2012) (Lilhaq et al ., 2017) (Winarno, 2018). 
6. Evaluasi kegiatan dilakukan secara bertahap sesuai dengan tahapan kerja dengan memperhatikan capaian indikator keberhasilan pada setiap tahapan.

\section{HASIL DAN PEMBAHASAN}

Kelompok peternak sangat antusias mengikuti penyuluhan dan pelatihan yang dilakukan tim pelaksana maupun pendamping (mahasiswa) untuk meningkatkan pengetahuan dan ketrampilan. Indikator yang dilihat adalah Kelompok mitra (peternak ayam kampung) mampu menyeleksi telur untuk ditetaskan dengan mesin tetas, memelihara anak ayam dengan metode brooding, dapat meningkatkan kinerja pertumbuhan ayam kampung dengan pakan lokal yang murah tapi berkualitas dan dapat membuat pupuk bokasi memanfaatkan ekskreta ayam.

Pola beternak pada kelompok mitra mulai berubah, seperti terlihat pada saat penetasan, induk ayam tidak dibiarkan mengeram telur tetapi telur ditetaskan dengan mesin tetas, sehingga induk lebih cepat untuk bertelur kembali (Wirapartha \& Dewi, 2017). Hal ini meningkatkan jumlah telur yang dihasilkan dari beberapa induk yang dipelihara sebelum afkir. Telur yang disortir dan memenuhi syarat penetasan di tetaskan dengan mesin, sedangkan yang tidak memenuhi syarat di konsumsi dan dijual walaupun jumlahnya sedikit. Harga jual telur pada saat pandemic Covid-19 ini Rp. 3.000/butir.

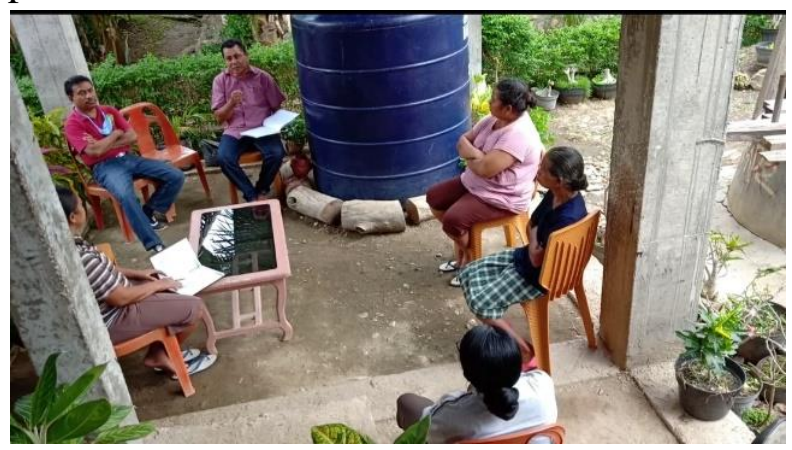

Gambar 1. Arahan dan ceramah Tim pengabdian kepada kelompok mitra

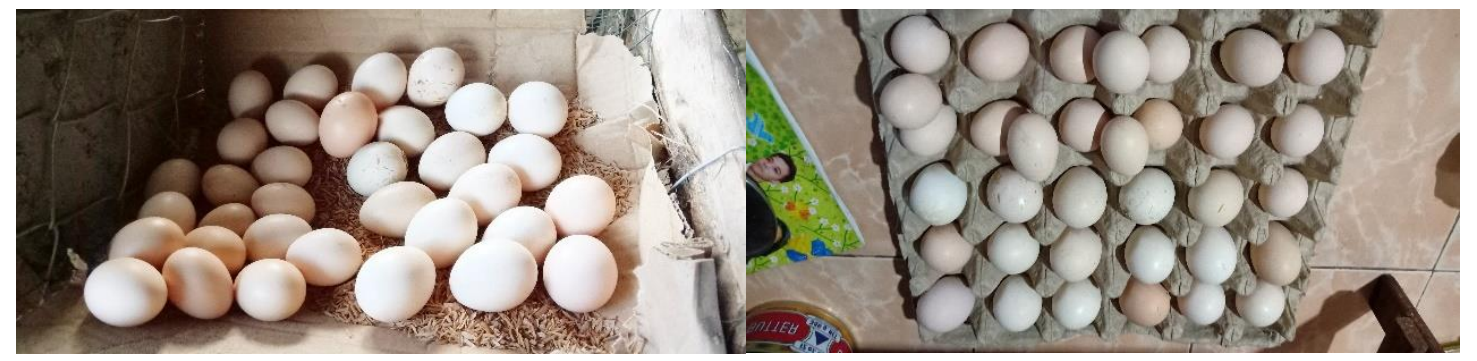

Gambar 2. Telur yang dihasilkan dari beberapa induk ayam kampung kelompok peternak 

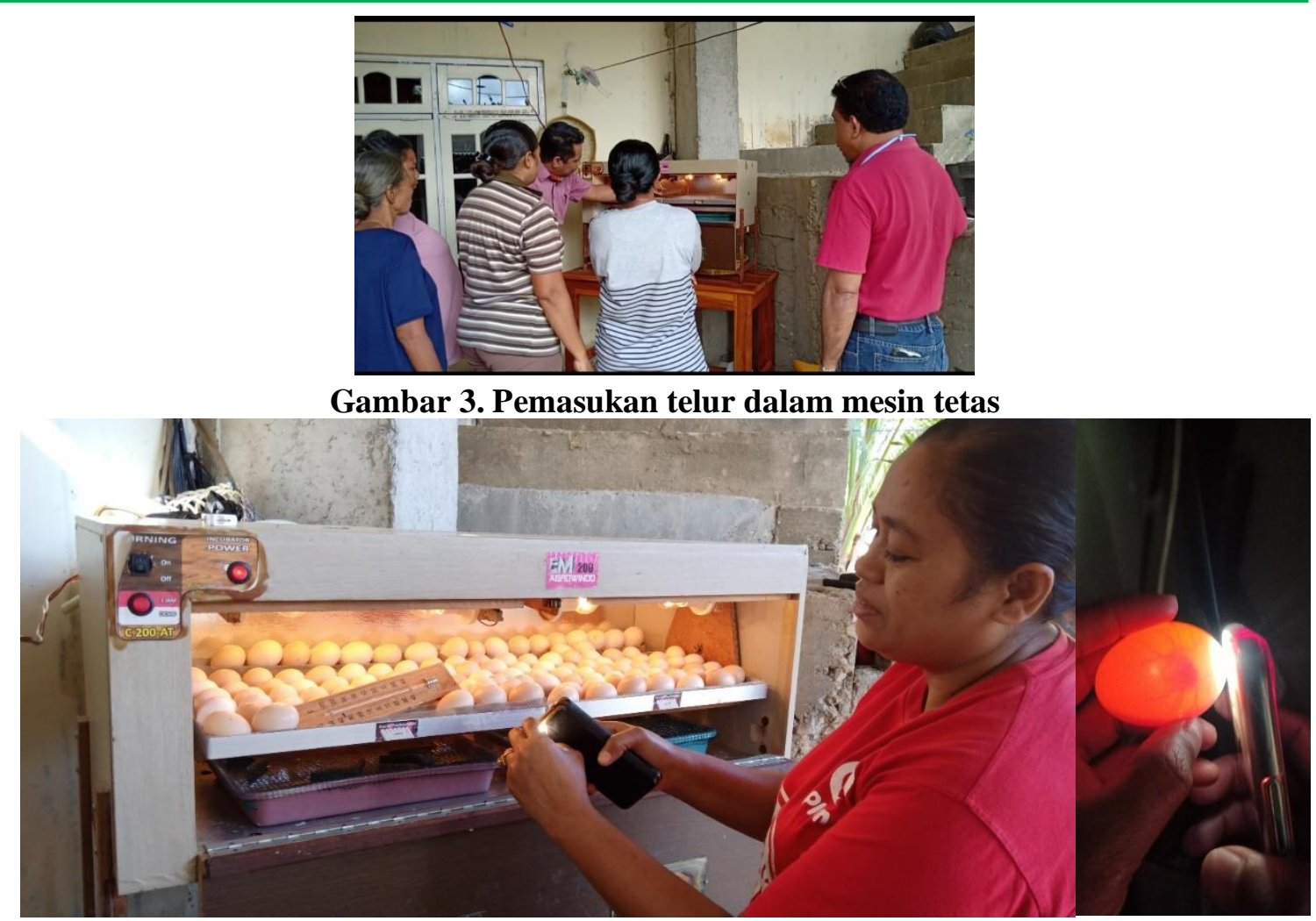

Gambar 4. Telur ayam kampung yang ditetaskan di kelompok peternak (sortir telur fertile)

Anak ayam hasil penetasan bertumbuh dengan baik karena dipelihara dalam kandang pemanas (brooding) dengan pola vaksinasi yang teratur. Hal ini dilihat dari pertambahan berat badan dan tingkat mortalitas dibawah $10 \%$. Pada pemeliharaan sebelum kegiatan pengabdian, tingkat mortalitas anak ayam sampai umur 6 minggu mencapai 25\%, dan meningkat menjadi 35$40 \%$ sampai fase grower jika pemeliharaan tidak dalam kandang indukan dan pola vaksinasi diabaikan.

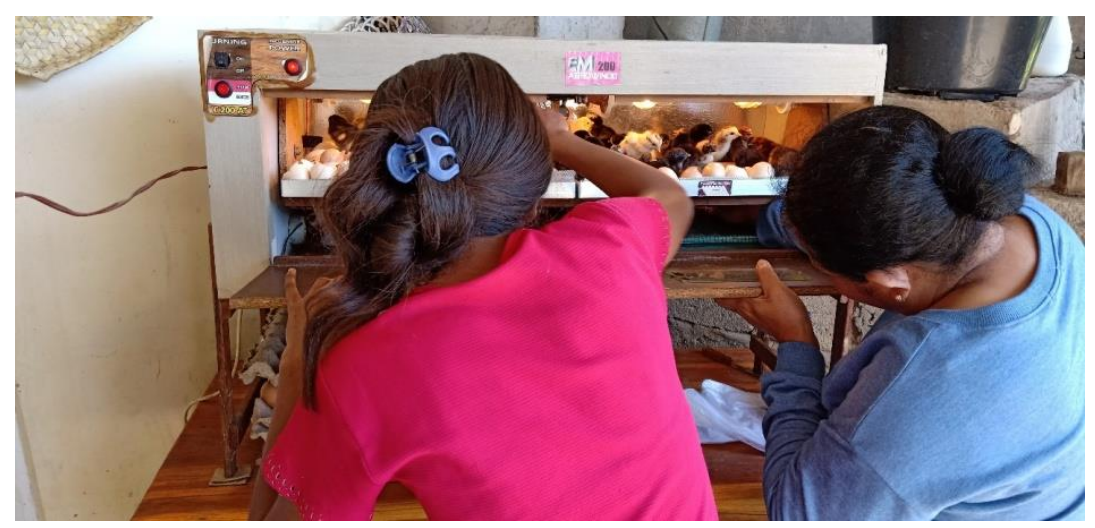

Gambar 5. Pengeluaran/pemindahan DOC dari mesin tetas ke brooding 


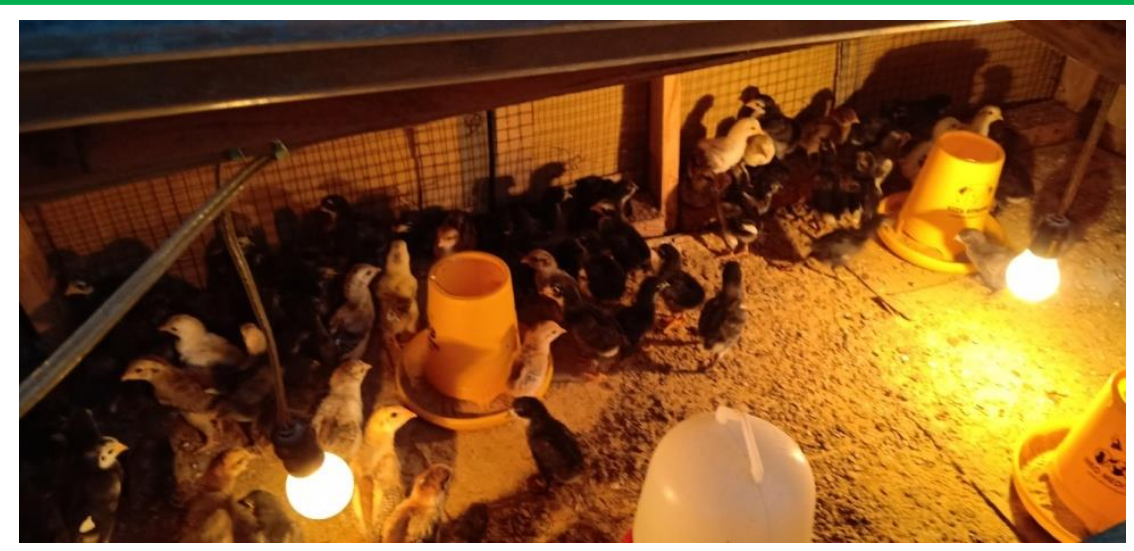

Gambar 6. DOC hasil Penetasan dan pemeliharaan dalam brooding

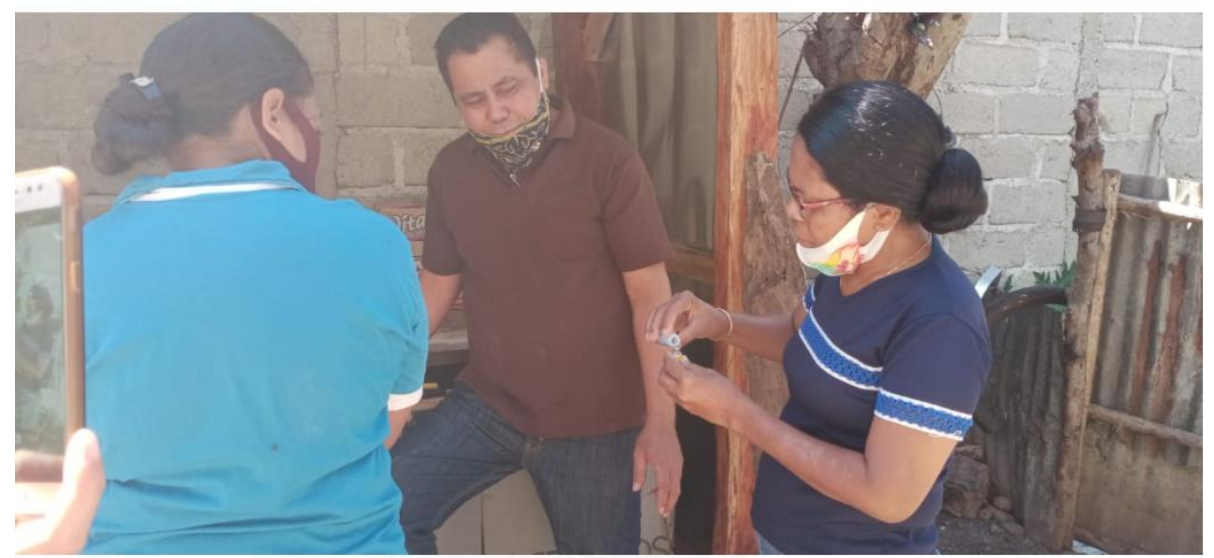

Gambar 7. Vaksinasi ND 1, tetes mata pada umur DOC 3 hari
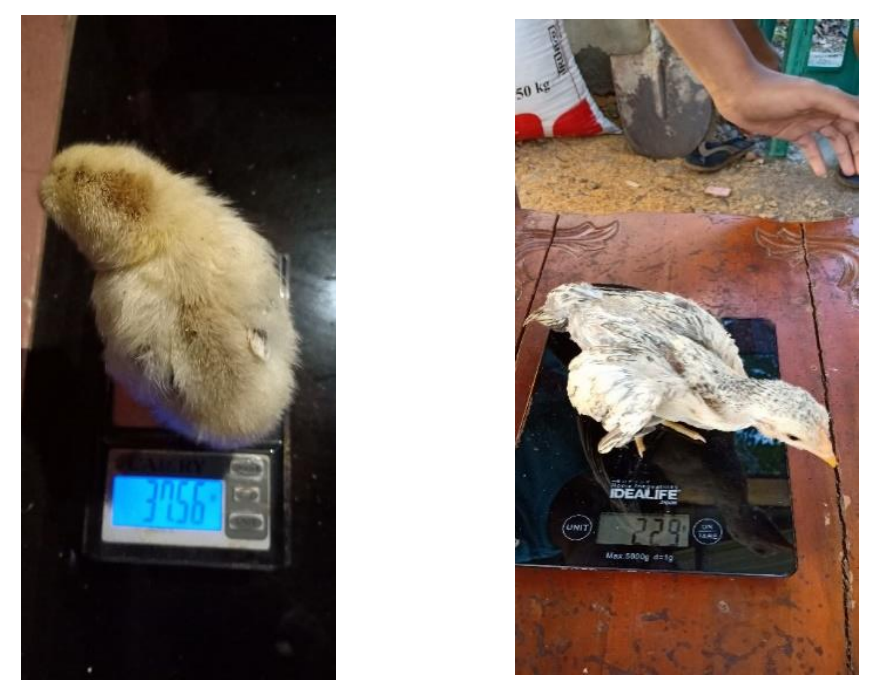

Gambar 8. Penimbangan berat DOC dan ayam umur 4 minggu

Pakan yang digunakan berasal dari bahan baku lokal yang lebih murah dengan tetap memperhatikan kualitasnya (Lisnahan, 2018). Bahan-bahan ini digiling dan dicampur sendiri menjadi ransum komplit untuk ayam kampung sesuai fase pemeliharaan. Dengan Ransum yang 


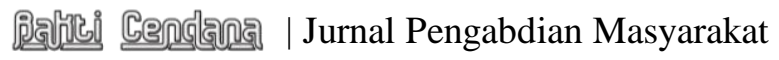

dibuat sendiri dapat menekan biaya pakan sebesar $40 \%$ jika dibandingkan dengan pakan dari poultry shop yang ada di Kefamenanu, NTT.

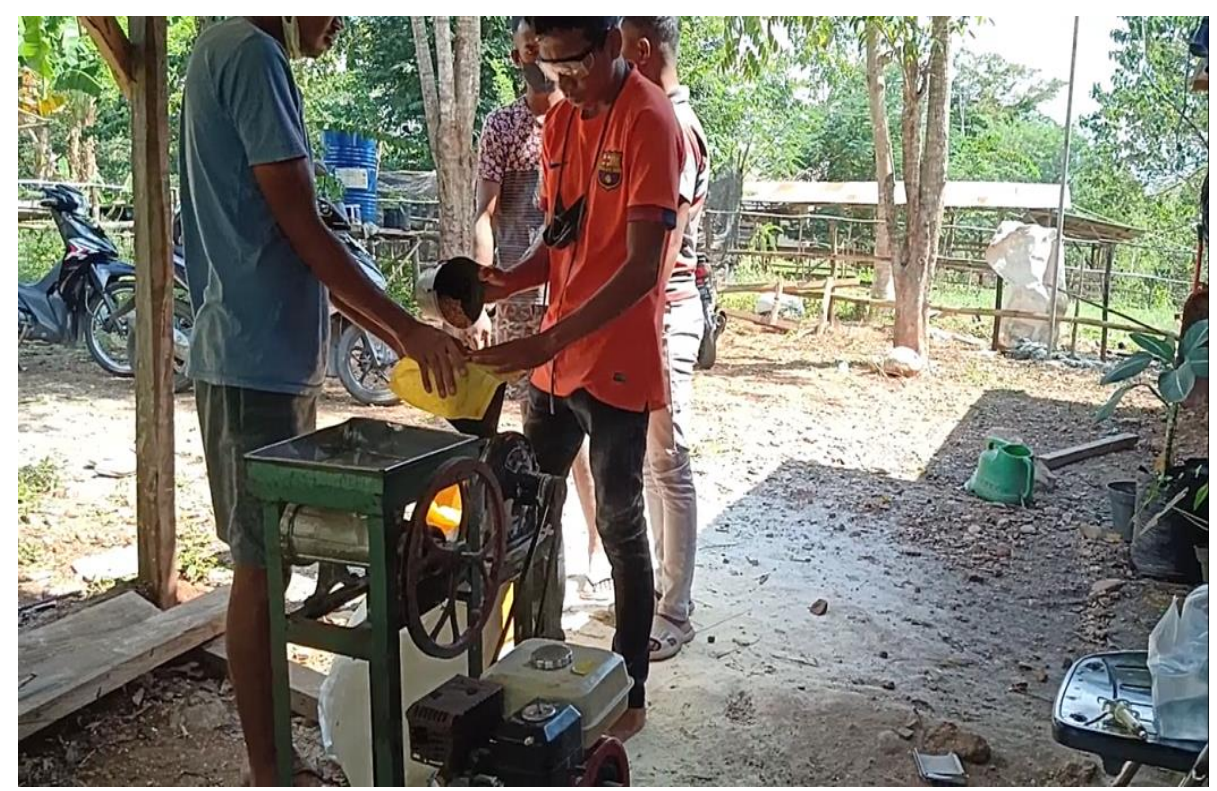

Gambar 9. Giling jagung dibantu oleh tim pendamping (mahasiswa)

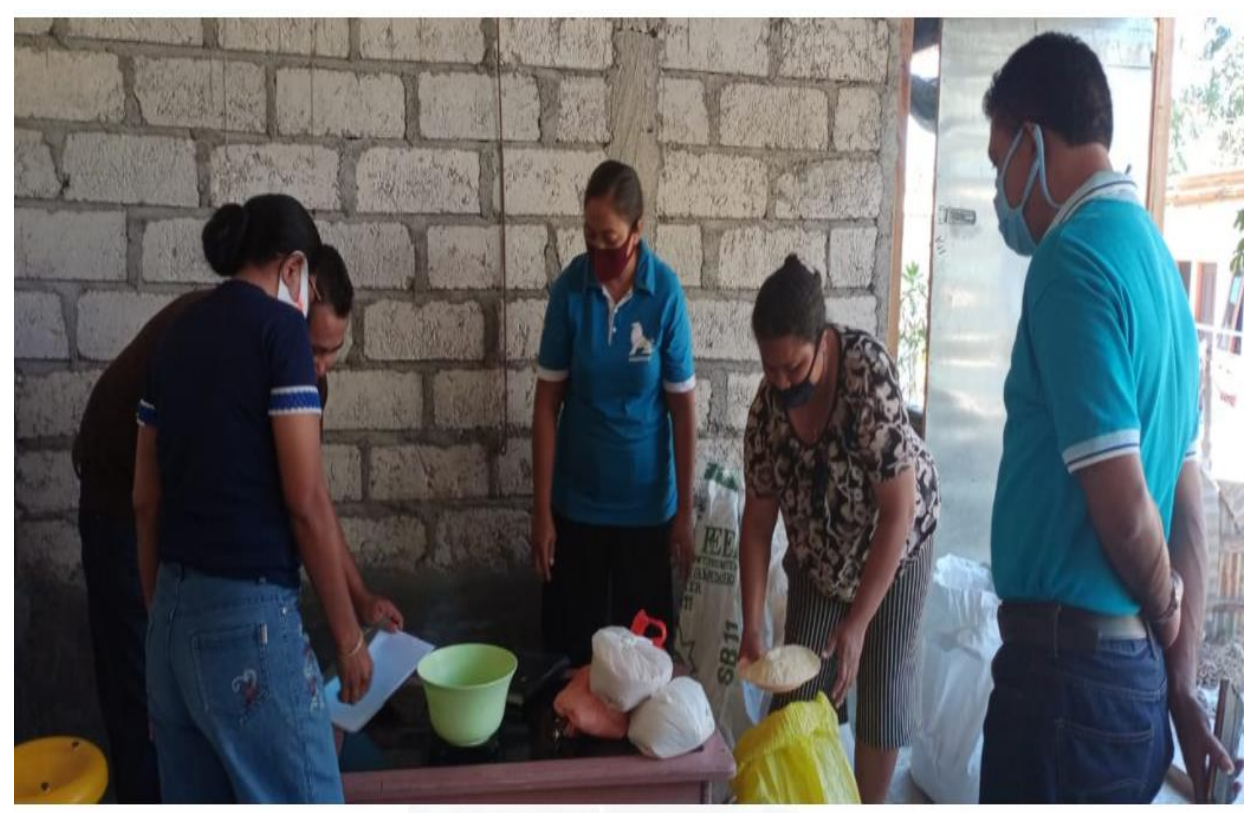

Gambar 10. Pencampuran pakan di kelompok mitra 


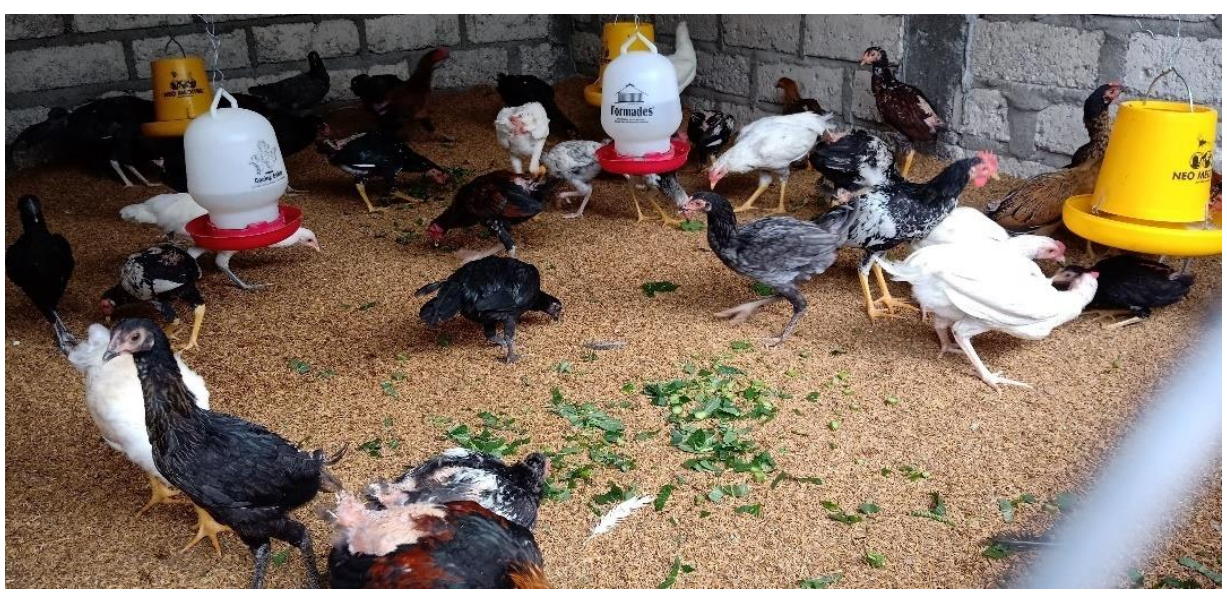

Gambar 11. Ayam kampung kelompok mitra umur 12 minggu

Tingkah laku sosial peternak mulai berubah dengan sentuhan ilmu dan teknologi yang diterapkan. Hal ini terlihat dari pengontrolan dan waktu yang disiapkan untuk ternak ayam bertambah.

Peningkatan pendapatan dan kesejahteraan bagi kelompok peternak dari penjualan ayam sebagai ternak daging mulai nampak setelah penjualan ayam per ekor. Penjualan ayam umur 3 bulan berkisar dari Rp. 60.000-70.000/ekor, sedangkan umur 4 sampai 5 bulan mencapai Rp. 100.000-120.000/ekor. Berat-rata-rata ayam kampung yang dijual adalah 1,2 -1,5 kg dengan angka konversi pakan 4,5. Dengan memperhitungkan biaya pakan per kilo Rp.6.000 maka seekor ayam membutuhkan pakan sebesar Rp. 27.000. Biaya lain-lain yang dikeluarkan adalah vaksinasi, peralatan seperti tempat pakan dan minum, sekam, kapur untuk alas lantai. Biaya lainlain sekitar Rp. 5.000/ekor. Dengan tingkat mortalitas 10\%, maka dari 100 DOC yang dipelihara, dengan harga jual ayam rata-rata Rp. 80.000 dapat dikalkulasikan keuntungan sebesar:

Penerimaan : 90 ekor X Rp. 80.000= Rp. 7.200.000

Biaya pakan : 4,5 kg X 100 ekor X Rp. $6.000=$ Rp. 2.700 .000

Biaya DOC : 100 ekor X Rp. 7.5000= Rp. 750.000

Biaya lain-lain (vaksin, vitamin, penyusutan tempat pakan/minum, penyusutan kandang) $=\mathrm{Rp}$. 5.000 X 100 ekor = 500.000(Dewanti \& Sihombing, 2012) (Wiranata et al., 2017).

Dengan demikian keuntungan yang diperoleh adalah Rp. 3.250.000

Produk sampingan dari limbah ternak (ekskreta) ayam dibuat pupuk bokasi. Pembuatan pupuk bokasi memanfaatkan kotoran ayam dengan pencampuran EM4 dan gula lontar (Kusuma \& Erviana, 2012). Pupuk ini dimanfaatkan kelompok untuk pemupukan sayur.

Dari kegiatan pengabdian ini, terjadi perubahan pada kelompok mitra yaitu:

1. Produksi telur dari induk ayam kelompok yaitu terjadi peningkatan frekuensi peneluran menjadi 2 kali dalam 4 bulan, dibandingkan sebelumnya 2-3 kali pertahun. Hal ini karena induk tidak diberi kesempatan untuk mengerami telur sendiri, tapi dierami dengan mesin tetas. Demikian juga jumlah telur terjadi peningkatan dari 45 butir/tahun menjadi 30 butir/4 bulan. 
2. Perubahan pada ketrampilan menggunakan mesin tetas, kelompok mitra berhasil menetaskan telur dengan tingkat fertilitas $85 \%$ dan daya tetas $70 \%$. Telur yang tidak fertile dalam 3 hari disortir dan $15 \%$ telur yang tidak fertil dikonsumsi kelompok mitra.

3. Pakan yang digunakan sebelumnya adalah Pakan BR 1 dan 2, limbah rumah tangga, dan ayam dibiarkan mencari sendiri di halaman rumah. Setelah dilakukan penyuluhan dan pelatihan maka pakan yang digunakan adalah konsentrat yang dibuat sendiri terdiri dari jagung giling, bekatul, tepung ikan, bungkil kedelai, kapur, asam amino methionine, lysine, premix mineral, premix vitamin. Harga pakan dapat ditekan Rp. 3.000/kg. Bahan pakan, semakin lengkap dan seimbang sesuai kebutuhan ternak setiap fase pemeliharaan.

4. Perubahan ketrampilan/pengetahuan terjadi karena sebelumnya kelompok kurang paham dan dan kurang terampil beternak ayam kampung, sekarang peternak telah terampil beternak ayam kampung. Peternak dapat menetaskan telur sendiri menggunakan alat tetas, memelihara dalam brooding, vaksinasi, pencampuran pakan, dan pemeliharaan fase grower, dan juga melakukan pembersihan kandang dan fumigasi secara rutin, dan dapat membuat pupuk bokasi.

5. Dampak sosial yang terjadi adalah lebih banyak waktu dan tenaga lebih dicurahkan untuk memelihara ayam kampung dar sebelumnya yaitu belum/kurang perhatian terhadap ternak ayam kampung yang dipelihara kelompok peternak.

\section{SIMPULAN}

Kesimpulan dari kegiatan pengabdian kepada masyarakat di Kelompok Ibu Rumah Tangga Perempuan Sion Kefamenanu NTT adalah adanya efektifitas dalam penerapan ilmu pengetahuan dan teknologi:

1. Kelompok peternak mempunyai antusias dan berpartisipasi dalam menggunakan alat tetas dan dapat menetaskan telur ayam kampung dengan baik.

2. Pemeliharaan dengan indukan buatan (brooding) dan pemeliharaan fase pertumbuhan (grower) serta manajemen pemeliharaan lainnya seperti pencegahan penyakit dan vaksinasi, pencampuran pakan dan lain-lain dapat dilakukan dengan mudah oleh kelompok peternak sehingga populasi maupun produktivitas ternak ayam kampung bertambah.

3. Terjadi peningkatan pendapatan dan kesejahteraan kelompok peternak dengan keuntungan Rp. 3.250.000 dengan volume pemeliharaan 100 ekor ayam kampung sejak DOC sampai umur 3-5 bulan.

Dari kegiatan pengabdian ini dapat disarankan agar perlu pendampingan berkelanjutan dan pengadaan fasilitas seperti mesin tetas agar peternak dapat meningkatkan pendapatannya dengan menjual DOC. Perlu pengadaan mesin penggiling pakan untuk kelompok peternak untuk dapat memanfaatkan bahan pakan lokal pada musim surplus seperti jagung kuning untuk menekan biaya variabel jika pakan langsung dibeli dari poultry shop. Solusi lain adalah adanya studi banding pada kelompok ternak yang telah lebih dahulu berhasil terutama ternak unggas sebagai contoh yang dapat digunakan untuk keberlanjutan dan memaksimalkan usaha peternak.

\section{UCAPAN TERIMAKASIH}


Kami mengucapkan banyak terimakasih kepada Kementerian Riset dan Teknologi/Badan Riset dan Inovasi Nasional, Deputi Bidang Penguatan Riset dan Pengembangan yang telah memberikan bantuan dana pengabdian melalui Hibah Program Kemitraan Masyarakat tahun 2020 .

\section{DAFTAR PUSTAKA}

Dewanti, R., \& Sihombing, G. 2012. Analisis Pendapatan Usaha Peternakan Ayam Buras (Studi Kasus di Kecamatan Tegalombo, Kabupaten Pacitan). Buletin Peternakan, 36(1), 48. https://doi.org/10.21059/buletinpeternak.v36i1.1276

Kementrian Pertanian Republik Indonesia. 2019. Statistik Peternakan dan Kesehatan Hewan 2019. Retrieved from https://ditjenpkh.pertanian.go.id/userfiles/File/Buku_Statistik_2019.pdf

Kusuma, \& Erviana, M. 2012. Pengaruh Beberapa Jenis Pupuk Kandang Terhadap Kualitas Bokashi. Jurnal Ilmu Hewani Tropika, 1(2), 41-46. Retrieved from unkripjournal.com

Lilhaq, O., Kaligis, D.A ., Kaunang, C. L., \& Rustandi. 2017. Pengaruh Level Bokashi Kotoran Ayam Dan Tingkat Kepadatan Populasi Tanaman Terhadap Pertumbuhan Vegetatif Sorgum Brown Midrib (Bmr). Zootec, 38(1), 37. https://doi.org/10.35792/zot.38.1.2018.17669

Lisnahan, C. V. 2018. Penentuan kebutuhan nutrien ayam kampung fase pertumbuhan yang dipelihara secara intensif dengan metode kafetaria (Universitas Gadjah Mada, Yogyakarta). Retrieved from https://scholar.google.co.id/citations?user=Y6Boe1oAAAAJ\&hl=id\#d=gs_md_cita$\mathrm{d} \& \mathrm{u}=\% 2$ Fcitations\%3Fview_op\%3Dview_citation\%26hl\%3Did\%26user\%3DY6Boe1oAA AAJ\%26citation_for_view\%3DY6Boe1oAAAAJ\%3ASe3iqnhoufwC\%26tzom\%3D-420

Lisnahan, C. V., Wihandoyo, Zuprizal, \& Harimurti, S. 2017a. Effect of addition of methionine and lysine into diets based on cafeteria standards on the growth performance of native chickens at starter phase. International Journal of Poultry Science, 16(12), 506-510. https://doi.org/10.3923/ijps.2017.506.510

Lisnahan, C. V., Wihandoyo, Zuprizal, \& Harimurti, S. 2017b. Growth performance of native chickens in the grower phase fed methionine and lysine-supplemented cafeteria standard feed. Pakistan Journal of Nutrition, 16(12), 940-944. https://doi.org/10.3923/pjn.2017.940.944

Winarno, D. 2018. Mengelola kotoran ayam layer. Infovet. Retrieved from http://www.majalahinfovet.com/2018/11/mengelola-kotoran-ayam-layer.html,

Wiranata, M. A., Sanyoto, J. I., \& Subagja, H. 2017. Analisis Profitabilitas Usaha Peternakan Ayam Kampung Super Di Kabupaten Jember. Jurnal Ilmu Peternakan Terapan, 1(1), 3138. https://doi.org/10.25047/jipt.v1i1.534

Wirapartha, M., \& Dewi, G. A. M. K. 2017. Bahan Ajar Manajemen Penetasan. Retrieved from https://simdos.unud.ac.id/uploads/file_pendidikan_1_dir/e2b2f64b38285f1b40e1c31add256 


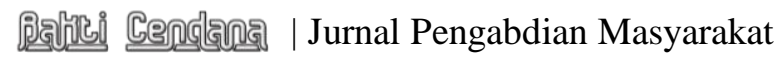

Volume 04, Nomor 01, Februari 2021
ISSN : 2622-6766 (online)

DOI : 0.32938/bc.v4i1.770

af5.pdf 